\title{
A Novel Sixteen Switch Three-Phase Nine- Level Voltage Source Inverter
}

\author{
VijayaKrishna Satyamsetti ${ }^{1}$, Rajendra Prasad Tenali ${ }^{2}$, Nagesh Kudupudi ${ }^{3}$ \\ Depaerment of Electrical and Electronics, Jawaharlal Nehru Technological University, \\ Kakinada, Rajahmahedravaram, AndhraPradesh, India \\ ${ }^{1}$ Vijayakrishna@ieee.org, ${ }^{2}$ rajendratce@gmail.com \\ ${ }^{3}$ kudupudi.nagesh211@gmail.com
}

\begin{abstract}
A novel method for a 3-phase nine-level voltage source inverter using sixteen switch is introduced. The given technique employs conventional 3-phase bridges of two-level as a diode clamped model. A de link voltage is supplied in such a way that the cascaded H-bridge produces the nine voltage levels. The switching patterns are stated as the levels increases then the pattern is difficult to produce three-phase outputs with fundamental modulation techniques. Here a solution for n-level inverter to produce required voltage-level with less number of power electronic components by setting up in the look-up tables. This study outlines the comparisons between nine-level voltage source inverters in different configurations and proposed novel sixteen switch three-phase inverter designed with less number of power electronic components and simulated in MATLAB/SIMULINK.
\end{abstract}

Keyword - Multilevel inverters, Look-up tables, Bidirectional Switches,

\section{INTRODUCTION}

The conventional voltage source inverter enables the synthesis of sinusoidal output voltage from several steps of voltages. The word multilevel has started with the three-level converter followed by numerous multilevel converter topologies. A wide range of topologies and control strategies are presented in literature [1][3]. A stack of multilevel inverter modules is designed for achieving low $d v / d t$ characteristics, low switching losses low harmonics in the output voltage and current and better electromagnetic interference. Due to several advantages, multilevel inverters have been applied in various application fields [4]-[8].

The cascaded multilevel inverter is developed by a number of single-phase H-bridge inverters and is categorized into symmetric and asymmetric based on the magnitude of the dc voltage sources. In the symmetric multilevel inverter, the magnitudes of the dc voltages are equal while, the asymmetric multilevel inverter, the values of the dc voltages are unequal. Recently, asymmetrical multilevel inverter and hybrid multistage topologies are becoming on of the most interested research area. This topology reduces the cost and size of the inverter and improves the reliability since minimum number of power electronic components, capacitors, and dc supplies used. The hybrid multistage converters consist of different multilevel configurations with unequal dc voltage supplies. With such converters, different modulation strategies and power electronic components technologies are needed [9]- [15].

However, the purpose of improving the performance of the conventional single and three-phase inverters, different topologies employed with different types of bidirectional switches has presented. By comparing the unidirectional and bidirectional switches, bidirectional switch is capable to conduct the current and withstanding the voltage in two-directions. For achieving the higher voltage levels, bidirectional switches with an appropriate modulation technique can improve the performance of voltage source inverter in terms of reducing the semi-conductor components and minimizing the withstanding voltages. Based on the technical background, this paper suggests a novel topology for a three-phase nine-level voltage source inverter with sixteen switches. Also extended structure for $\mathrm{N}$-level is presented and compared by different trending topologies.

\section{PROPOSED TOPOLOGY}

\section{A. Modelling}

The proposed nine level voltage source inverter consists three-bidirectional switches (S1-S6), two diodes (Da1$\mathrm{Da} 2)$, are added to the conventional three-phase two-level bridge (Q1-Q6) as shown in Fig.1. The function of these bidirectional switches is to block the higher voltage and ease current flow to and from the midpoint (o). There by VSI is fed with a fixed voltage of $4 \mathrm{Vdc}$ and two cascaded bridges are fed with to unequal voltages $\mathrm{Vdc}$ and $2 \mathrm{Vdc}$ are connected to $(+,-$, o) terminals. Hence the presented VSI is functioned to generate nine equal and different voltage levels, the power circuit of the cascaded H-bridge makes use of two series cells having unequal voltage supplies. In each cell two switches are turned On and OFF under inverted conditions to output two voltage levels. 


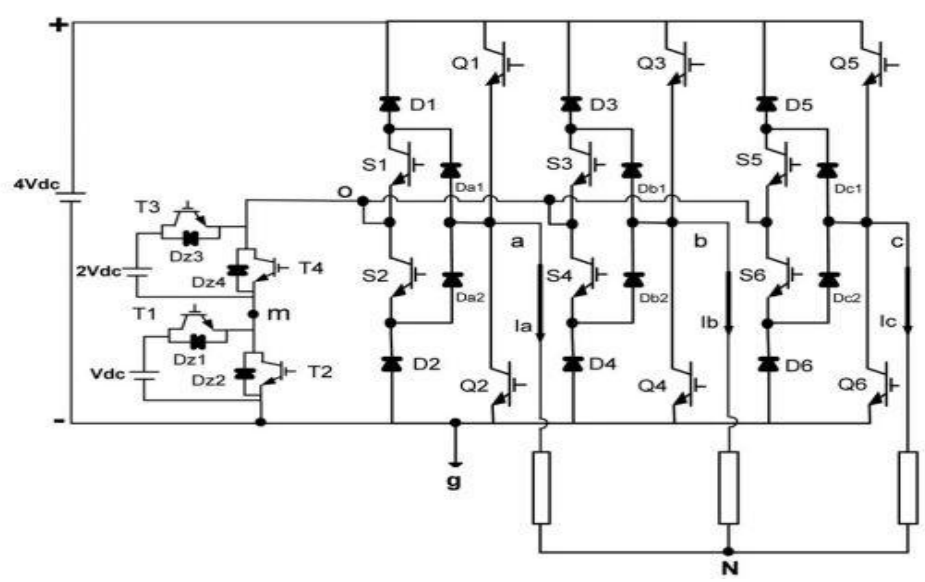

Fig .1. Circuit diagram for proposed sixteen switch nine-level voltage source inverter.

withcorresponding voltages Vdc,2Vdc,3Vdc,4Vdc.0 -Vdc,-2Vdc, The first cell dc voltage supply Vdc is added if switch T1 is turned ON leading to Vmg=Vdc where Vmg is the voltage at node (m)with respect to inverter ground (g)or bypassed if switch T2 is turned ON leading toVmg $=0$. Likewise, the second cell dc voltage supply $2 \mathrm{Vdc}$ is added when switch T3 is turned ON resulting in Vom=+2Vdc where Vom is the voltage at midpoint (o) with respect to node $(\mathrm{m})$ or bypassed when switch $\mathrm{T} 4$ is turned $\mathrm{ON}$ resulting inVom $=0$. The peak voltage rating of the switches of the conventional two level bridge (Q1-Q6) is 4Vdcwhereas the bidirectional switches (S1-S6) have a peak voltage rating of 3Vdc.InCHBcells,the peak voltage rating of second cell switches (T3 and T4) is 2Vdc while the peak voltage rating of $\mathrm{T} 1$ and $\mathrm{T} 2$ in the first cell is Vdc. By total Vab, Vbc, Vca with corresponding voltages Vdc,2Vdc,3Vdc,4Vdc.0 -Vdc,-2Vdc,-3Vdc,-4Vdc as shown in Fig.2.

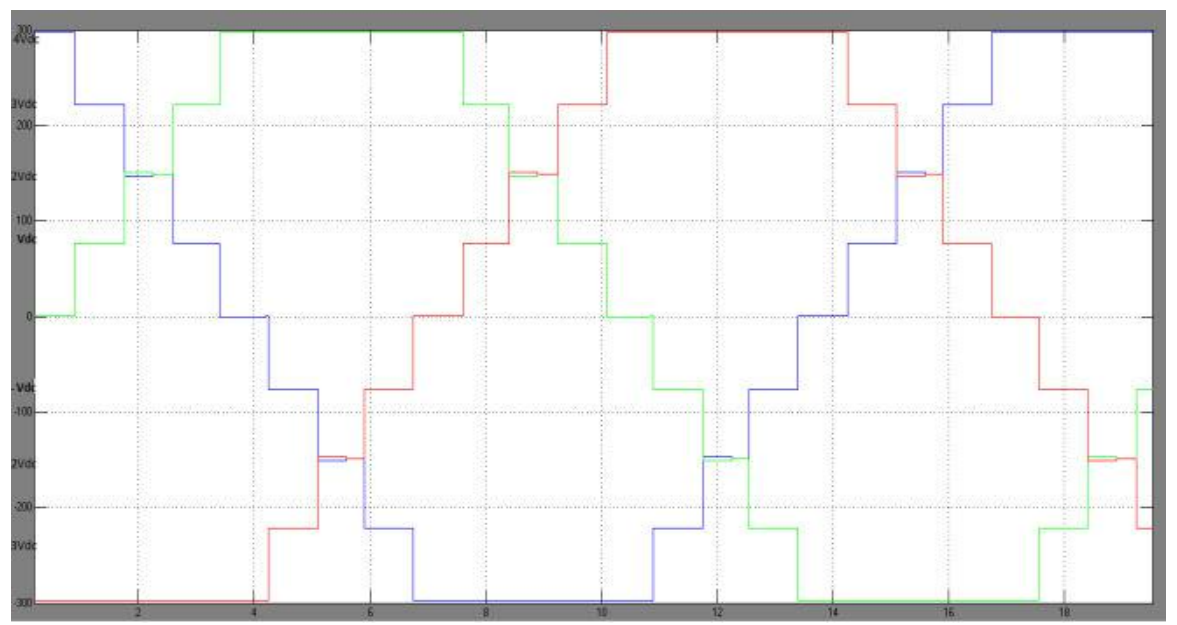

Fig.2. Simulated waveforms of Vab, Vbc, Vca with corresponding voltages Vdc,2Vdc,3Vdc,4Vdc .0 - Vdc,-2Vdc,-3Vdc,-4Vdc

The balanced load voltages can be achieved if the proposed inverter operates on the switching states depicted in Table I. The inverter may have 24 different modes within a cycle of the output waveform. The inverter line-to-line voltage waveforms $\mathrm{Vab}$, Vbc, and Vca with corresponding switching gate signals are depicted in Table I.

$$
\left[\begin{array}{l}
V_{\mathrm{ab}} \\
V_{\mathrm{bc}} \\
V_{\mathrm{ca}}
\end{array}\right]=\left[\begin{array}{ccc}
1 & -1 & 0 \\
0 & 1 & -1 \\
-1 & 0 & 1
\end{array}\right] *\left[\begin{array}{l}
V_{\mathrm{ag}} \\
V_{\mathrm{bg}} \\
V_{\mathrm{cg}}
\end{array}\right]
$$


TABLE I. LOOK-UP TABLES SEQUENCE OF THE PROPOSED NINE-LEVEL INNVERTER

\begin{tabular}{|c|c|c|c|c|c|c|c|c|c|c|c|c|c|c|c|c|c|c|c|}
\hline S & Q1 & Q2 & Q3 & Q4 & Q5 & Q6 & S1 & S2 & S3 & S4 & S5 & S6 & T1 & T2 & T3 & T4 & VA & VB & VC \\
\hline $\mathrm{t} 1$ & 1 & 0 & 0 & 1 & 0 & 1 & 0 & 0 & 0 & 0 & 0 & 0 & 1 & 0 & 0 & 1 & 4 & 0 & 0 \\
\hline $\mathrm{t} 2$ & 1 & 0 & 0 & 0 & 0 & 1 & 0 & 0 & 1 & 1 & 0 & 0 & 1 & 0 & 0 & 1 & 4 & 1 & 0 \\
\hline $\mathrm{t} 3$ & 1 & 0 & 0 & 0 & 0 & 1 & 0 & 0 & 1 & 1 & 0 & 0 & 0 & 1 & 1 & 0 & 4 & 2 & 0 \\
\hline $\mathrm{t} 4$ & 1 & 0 & 0 & 0 & 0 & 1 & 0 & 0 & 1 & 1 & 0 & 0 & 1 & 0 & 1 & 0 & 4 & 3 & 0 \\
\hline $\mathrm{t} 5$ & 1 & 0 & 1 & 0 & 0 & 1 & 0 & 0 & 0 & 0 & 0 & 0 & 1 & 1 & 1 & 0 & 4 & 4 & 0 \\
\hline $\mathrm{t} 6$ & 1 & 0 & 1 & 0 & 0 & 1 & 1 & 1 & 0 & 0 & 0 & 0 & 1 & 1 & 1 & 0 & 3 & 4 & 0 \\
\hline $\mathrm{t} 7$ & 0 & 0 & 1 & 0 & 0 & 1 & 1 & 1 & 0 & 0 & 0 & 0 & 0 & 1 & 1 & 0 & 2 & 4 & 0 \\
\hline $\mathrm{t} 8$ & 0 & 0 & 1 & 0 & 0 & 1 & 1 & 1 & 0 & 0 & 0 & 0 & 1 & 0 & 0 & 1 & 1 & 4 & 0 \\
\hline $\mathrm{t} 9$ & 0 & 1 & 1 & 0 & 0 & 1 & 0 & 0 & 0 & 0 & 0 & 0 & 1 & 0 & 0 & 1 & 0 & 4 & 0 \\
\hline $\mathrm{t} 10$ & 0 & 1 & 1 & 0 & 0 & 0 & 0 & 0 & 0 & 0 & 1 & 1 & 1 & 0 & 0 & 1 & 0 & 4 & 1 \\
\hline $\mathrm{t} 11$ & 0 & 1 & 1 & 0 & 0 & 0 & 0 & 0 & 0 & 0 & 1 & 1 & 0 & 1 & 1 & 0 & 0 & 4 & 2 \\
\hline $\mathrm{t} 12$ & 0 & 1 & 1 & 0 & 0 & 0 & 0 & 0 & 0 & 0 & 1 & 1 & 1 & 0 & 1 & 0 & 0 & 4 & 3 \\
\hline $\mathrm{t} 13$ & 0 & 1 & 1 & 0 & 1 & 0 & 0 & 0 & 0 & 0 & 0 & 0 & 1 & 0 & 1 & 0 & 0 & 4 & 4 \\
\hline $\mathrm{t} 14$ & 0 & 1 & 0 & 0 & 1 & 0 & 0 & 0 & 1 & 1 & 0 & 0 & 1 & 0 & 1 & 0 & 0 & 3 & 4 \\
\hline $\mathrm{t} 15$ & 0 & 1 & 0 & 0 & 1 & 0 & 0 & 0 & 1 & 1 & 0 & 0 & 0 & 1 & 1 & 0 & 0 & 2 & 4 \\
\hline $\mathrm{t} 16$ & 0 & 1 & 0 & 0 & 1 & 0 & 0 & 0 & 1 & 1 & 0 & 0 & 1 & 0 & 0 & 1 & 0 & 1 & 4 \\
\hline $\mathrm{t} 17$ & 0 & 1 & 0 & 1 & 1 & 0 & 0 & 0 & 0 & 0 & 0 & 0 & 1 & 0 & 0 & 1 & 0 & 0 & 4 \\
\hline $\mathrm{t} 18$ & 0 & 0 & 0 & 1 & 1 & 0 & 1 & 1 & 0 & 0 & 0 & 0 & 1 & 0 & 0 & 1 & 1 & 0 & 4 \\
\hline $\mathrm{t} 19$ & 0 & 0 & 0 & 1 & 1 & 0 & 1 & 1 & 0 & 0 & 0 & 0 & 0 & 1 & 1 & 0 & 2 & 0 & 4 \\
\hline $\mathrm{t} 20$ & 0 & 0 & 0 & 1 & 1 & 0 & 1 & 1 & 0 & 0 & 0 & 0 & 1 & 0 & 1 & 0 & 3 & 0 & 4 \\
\hline $\mathrm{t} 21$ & 1 & 0 & 0 & 1 & 1 & 0 & 0 & 0 & 0 & 0 & 0 & 0 & 1 & 0 & 1 & 0 & 4 & 0 & 4 \\
\hline $\mathrm{t} 22$ & 1 & 0 & 0 & 1 & 0 & 0 & 0 & 0 & 0 & 0 & 1 & 1 & 1 & 0 & 1 & 0 & 4 & 0 & 3 \\
\hline $\mathrm{t} 23$ & 1 & 0 & 0 & 1 & 0 & 0 & 0 & 0 & 0 & 0 & 1 & 1 & 0 & 1 & 1 & 0 & 4 & 0 & 2 \\
\hline $\mathrm{t} 24$ & 1 & 0 & 0 & 1 & 0 & 0 & 0 & 0 & 0 & 0 & 1 & 1 & 1 & 0 & 0 & 1 & 4 & 0 & 1 \\
\hline
\end{tabular}

It is worth noting that all simulated waveforms are obtained at $\mathrm{t} 1=\mathrm{t} 2=\cdots=\mathrm{t} 24=0.02 / 24 \mathrm{~s}$. In order to plot the space vector diagram of the proposed inverter in a stationary $d-q$ reference frame, the following equations can be used to derive $\mathrm{d}$ and $\mathrm{q}$ voltage components for all inverter vectors:

$$
\begin{gathered}
V_{\mathrm{q}}=\frac{4 \mathrm{~V}_{d e}}{3(\mathrm{~N}-1)}(2 \mathrm{Sa}-\mathrm{Sb}-\mathrm{Sc}) \\
V_{\mathrm{q}}=\frac{4 \mathrm{~V}_{d c}}{\sqrt{3}(\mathrm{~N}-1)}(\mathrm{Sc}-\mathrm{Sb}) \\
\quad \mathrm{V}=\mathrm{V}_{\mathrm{q}}-\mathrm{j} \mathrm{V}_{\mathrm{d}}
\end{gathered}
$$

where Vab,Vbc, and Vca are related to Vag,Vbg, and Vcg

\section{SWITCHING ALGORITHM}

The carrier based is the simplest modulation technique for unequal voltages sources. Carrier with Selective harmonic is the most common modulation technique used to control the fundamental output voltage as well as to eliminate the undesirable harmonic components from the output voltages. However, an iterative method such as Newton-Rapson method is normally used to find the solutions to $(\mathrm{N}-1)$ nonlinear transcendal equations. The difficult calculations and the need of high performance controller for the real application are the main disadvantages of such method.

Therefore, an alternative method is proposed to generate the inverter's switching gate signals. It is easier to control the proposed inverter and achieve the required output voltage waveforms in terms of Sa, Sb, and Sc as shown in Fig.3.The basis of the proposed method can be explained as following: For a given value of modulation index Ma and within a full cycle of the operation of the proposed inverter, the switching states Sa, $\mathrm{Sb}$, and Scare determined instantaneously. 


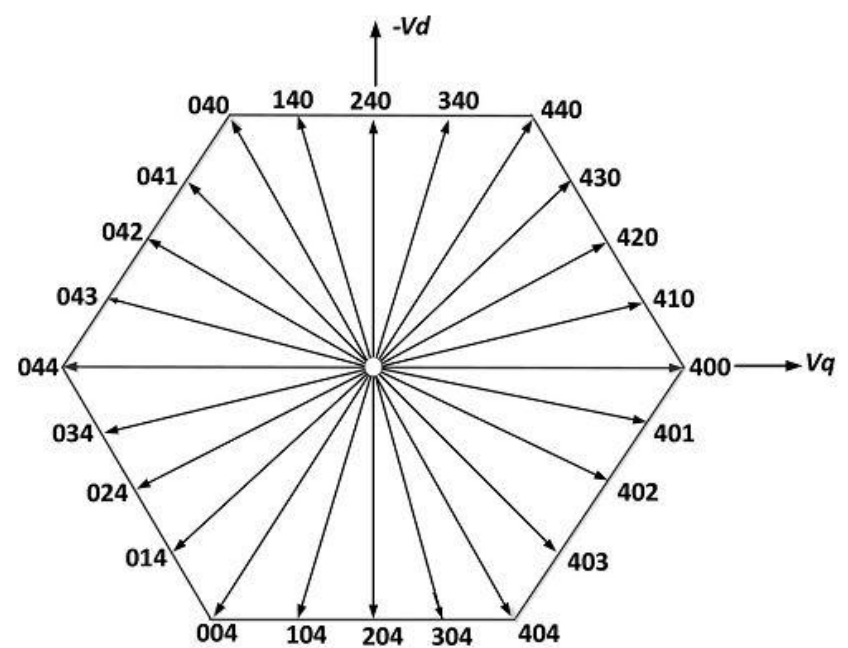

Fig. 3. Switching states vectors of the proposed inverter in $\mathrm{d}-\mathrm{q}$ reference frame

\section{EXTENDED STRUCUTRE}

We can observe that there is a possibility to reach an output voltage with higher number of steps in the proposed voltage source inverter by adding cascaded H-bridge in series as shown in Fig. 4. In order to achieve the desired number of voltage levels, the following method for the magnitudes of dc voltage supplies are:

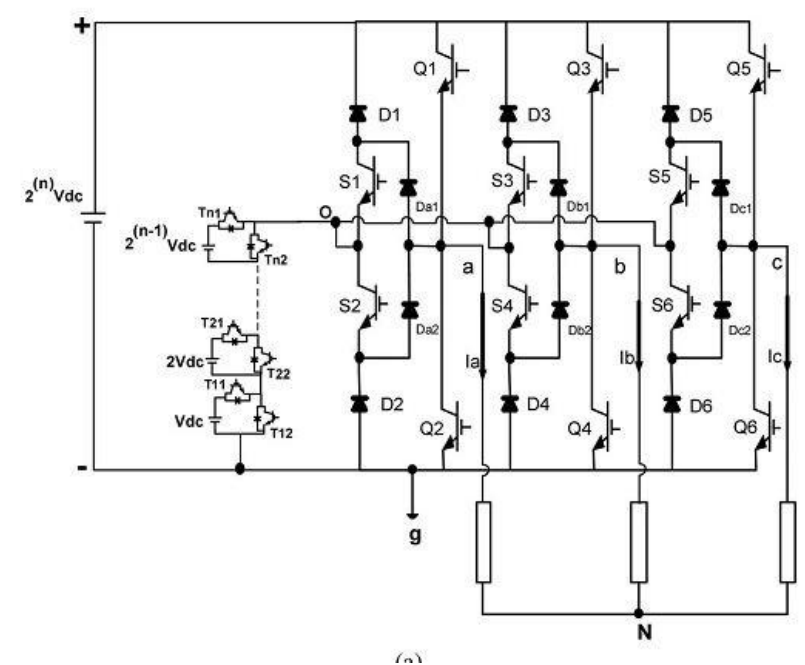

Fig.4. Circuit diagram of the proposed three-phase N-level voltage source inverter.

By making the binary relationship between the dc supplies of the cascaded h-bridge structure as follows:

MATLAB/Simulink model of the proposed inverter shown in Fig. 1 has been developed to study the conduction and switching power losses. The proposed inverter is designed to deliver output power of Pout=1.9 $\mathrm{kW}$. Three-phase series resistive-inductive $\mathbf{( 2 3 \Omega}-3 \mathrm{mH} /$ Phase) in star connection is used as load. The multilevel dc link is determined as $\mathrm{Vdc}=75 \mathrm{~V}, 2 \mathrm{Vdc}=150 \mathrm{~V}$, and Vfix $=4 \mathrm{Vdc}=300 \mathrm{~V}$ and the proposed carrier modulation technique at $\mathrm{Ma}=1$ is implemented to generate the appropriate switching gate signals. Three different types of semiconductor components are selected to build the prototype of the proposed inverter power circuit as following: IGBT (HGTG20N60B3D) $600 \mathrm{~V} / 40 \mathrm{~A}$ for the two-level Bridge and CHB switches, IGBT (IRG4BC40W) $600 \mathrm{~V} / 20$ A for bidirectional switches, and Diode (RHRP1540) $400 \mathrm{~V} / 15 \mathrm{~A}$ for embedded diodes in bidirectional switches and freewheeling diodes. 


\section{COMPARISION STUDY}

\begin{tabular}{|c|c|c|c|c|}
\hline Topology & $\begin{array}{c}\text { Clamped } \\
\text { Diodes }\end{array}$ & $\begin{array}{c}\text { Flying } \\
\text { Capacitors }\end{array}$ & $\begin{array}{c}\text { Cascaded } \\
\text { H-bridge }\end{array}$ & Proposed \\
\hline $\begin{array}{c}\text { Power Semi } \\
\text { conductor } \\
\text { Switches }\end{array}$ & $48 \mathrm{~S}$ & $48 \mathrm{~S}$ & $48 \mathrm{~S}$ & $16 \mathrm{~S}$ \\
\hline $\begin{array}{c}\text { Clamped } \\
\text { Diodes three } \\
\text { phase }\end{array}$ & 18 & 0 & 0 & 12 \\
\hline $\begin{array}{c}\text { DC bus } \\
\text { capacitor }\end{array}$ & 8 & 8 & 4 & 3 \\
\hline $\begin{array}{c}\text { Balancing } \\
\text { capacitors } \\
\text { three phase }\end{array}$ & 0 & 28 & 0 & 0 \\
\hline $\begin{array}{c}\text { Voltage } \\
\text { unbalancing }\end{array}$ & Average & High & $\begin{array}{c}\text { Very } \\
\text { small }\end{array}$ & small \\
\hline
\end{tabular}

Based on the comparison carried among the proposed method, the following observations are taken.

1) Commpared to all the aspects, Proposed three-phase voltage source inverter requires less power electronics components and less size with low voltage handlinng stress .

2) On the other hand, the voltage and current ratings of the power components have an effect on the cost and realization of the voltage source inverter.

Assuming that all power components have an equal current rating which is the rated current of the load (IL), the voltage ratings of these components depend on the magnitude of dc voltage supplies, voltage stress, and structure of the inverter.

Considering that all inverters have the same input dc link which equals $(\mathrm{N}-1) \mathrm{Vdc}$.

The proposed inverter is designed to deliver output power of Pout $=1.9 \mathrm{~kW}$. Three-phase series resistive-

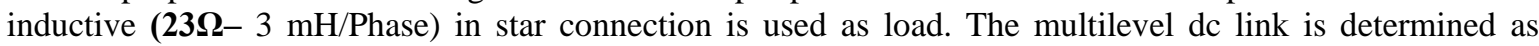
$\mathrm{Vdc}=75 \mathrm{~V}, 2 \mathrm{Vdc}=150 \mathrm{~V}$, and Fix $=4 \mathrm{Vdc}=300 \mathrm{~V}$ and the proposed carrier modulation technique at $\mathrm{Ma}=1$ is implemented to generate the appropriate switching gate signals. Three different types of semiconductor components are selected to build the proposed inverter power circuit as following: IGBT (HGTG20N60B3D) $600 \mathrm{~V} / 40 \mathrm{~A}$ for the two-level Bridge and CHB switches, IGBT (IRG4BC40W) $600 \mathrm{~V} / 20 \mathrm{~A}$ for bidirectional switches, and Diode (RHRP1540) 400 V/15 A for embedded diodes in bidirectional switches and freewheeling diodes.

\section{CONCLUSION}

In this paper, a novel control technique suitable for high power low switching frequency sixteen switch three-phase nine-level inverter is introduced. In order to minimize the switching devices different voltage sources as configured by bridge circuit and clamped by diode. Therefore the proposed topology results in reduction of installation area and cost. The fundamental frequency modulation was comfortably employed and showed high flexibility and simplicity in control. Moreover, the proposed technique was extended to N-level with different methods. The proposed topology was compared with the different kinds of techniques in literature from different points of view. According to the comparison results, the proposed topology requires a lesser number of power diodes, IGBTs, driver circuits, and dc voltage sources. The performance accuracy of the proposed sixteen switch three-phase nine-level inverter was verified through the MATLAB simulation.

\section{REFERENCES}

[1] J. Rodriguezet al., "Multilevel inverters: A survey of topologies, controls, and applications,"IEEE Trans. Ind. Electron., vol. 49, no. 4, pp. 724-738, Aug. 2002.

[2] L. G. Franqueloet al., “The age of multilevel converters arrives,” IEEE Ind. Electron. Mag., vol. 2, no. 2, pp. 28-39, Jun. 2008.

[3] I. Colaket al., "Review of multilevel voltage source inverter topologies and control schemes,"Energy Convers. Manage., vol. 52, pp. 1114- 1128, 2011.

[4] G.Bergna,E.Berne,P.Egrot,P.Lefranc,A.Arzande,J.-C.Vannier, and M. Molinas, “An energy-based controller for HVDC modular multilevel converter in decoupled double synchronous reference frame for voltage oscillation reduction,”IEEE Trans. Ind. Electron., vol. 60, no. 6, pp. 2360-2371, Jun. 2013.

[5] Z. Shu, N. Ding, J. Chen, H. Zhu, and X. He, "Multilevel SVPWM with DC-link capacitor voltage balancing control for diodeclamped multilevel converter based STATCOM,’”EEE Trans. Ind. Electron., vol. 60, no. 5, pp. 1884-1896, May 2013. 
[6] J. Chavarria, D. Biel, F. Guinjoan, C. Meza, and J. J. Negroni, "Energybalance control of PV cascaded multilevel grid-connected inverters under level-shifted and phase-shifted PWMs,”IEEE Trans. Ind. Electron., vol. 60, no. 1, pp. 98-111, Jan. 2013.

[7] G. Buticchi, E. Lorenzani, and G. Franceschini, "A five-level single-phase grid-connected converter for renewable distributed systems,”IEEE Trans. Ind. Electron., vol. 60, no. 3, pp. 906-918, Mar. 2013.

[8] J. A. Munoz, J. R R. Espinoza, C. R. Baier, L. L. Morán, E. E. Espinosa, P. E. Melín, and D. G. Sbárbaro, "Design of a discrete-time linear control strategy for a multicell UPQC,” IEEE Trans. Ind. Electron., vol. 59, no. 10, pp. 3797-3807, Oct. 2012.

[9] J. Ebrahimi, E. Babaei, and G. B. Gharehpetian, "A new topology of cascaded multilevel converters with reduced number of components for high-voltage applications,”IEEE Trans. Power Electron., vol. 26, no. 11, pp. 3109-3118, Nov. 2011.

[10] S. Mariethoz, "Systematic design of high-performance hybrid cascaded multilevel inverters with active voltage balance and minimum switching losses,”IEEE Trans. Power Electron., vol. 28, no. 7, pp. 3100- 3113, Jul. 2013.

[11] E. Babaei, “A cascade multilevel converter topology with reduced number of switches," IEEE Trans. Power Electron., vol. 23, no. 6, pp. 2657-2664, Nov. 2008.

[12] H. Belkamel, S. Mekhilef, A. Masaoud, and M. Abdel Naiem, "Novel three phase asymmetrical cascaded multilevel voltage source inverter,” IET Power Electron., vol. 6, pp. 1696-1706, 2013.

[13] S. Mekhilef and M. N. Abdul Kadir, "Voltage control of three-stage hybrid multilevel inverter using vector transformation,”IEEE Trans. Power Electron., vol. 25, no. 10, pp. 2599-2606, Oct. 2010.

[14] J. Meiet al., "Modular multilevel inverter with new modulation method and its application to photovoltaic grid-connected generator,”IEEE Trans. Power Electron., vol. 28, no. 11, pp. 5063-5073, Nov. 2013.

[15] A. Nami et al., "A hybrid cascade converter topology with seriesconnected symmetrical and asymmetrical diode-clamped H-bridge cells,” IEEE Trans. Power Electron., vol. 26, no. 1, pp. 51-65, Jan. 2011.

\section{BIOGRAPHIES}

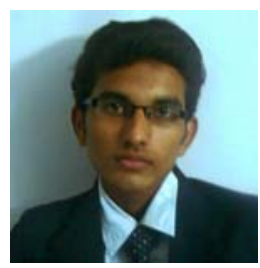

VijayaKrishna Satyamsetti received the B.Tech degree in electrical and electronics engineering from Jawaharlal Nehru technological university, Kakinada, India, in 2013, and the M.Tech in power electronics and power systems Jawaharlal Nehru technological university, Kakinada, India, in 2015. He worked as a research assistant in Krest Technologies Hyderabad, India for two years, also as a assistant professor in BVC college of engineering, Rajahmundry, India from 2015-2017.Since February 2017, he has been a Research Engineer at the University of Nicosia and working towards his PhD in Electrical Engineering .He is the author of more than 15 journal and conference papers. His research interests include FACTS devices, power quality enhancement in distribution systems, Wireless communication, Photonic devices and high frequency power electronic converters.

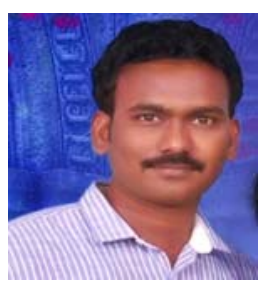

Rajendra Prasad Tenali is a Assistant Professor in Electrical and electronics Engineering in BVC College of engineering, Rajahmundry, India. He is working towards his $\mathrm{PhD}$ in Electrical Engineering in Jawaharlal Nehru Technological University, Kakinada and published more than 15 international journals and 5 international conferences. His current research includes FACTS, power quality improvement in smart-grid applications, reactive power compensation in IEEE bus systems and voltage stability problems, future energy networks and HVDC and VSC converters.

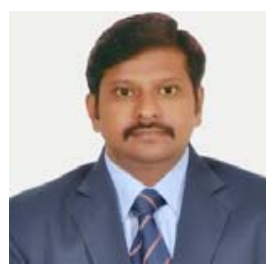

Nagesh Kudupudi is currently an Associate professor in BVC College of engineering, Rajahmundry and Principal in BVC Polytechnic College Rajahmundry, India. He is working towards his $\mathrm{PhD}$ in Electrical Engineering in Jawaharlal Nehru Technological University, Ananthapur, India. His interests are in the areas of size reduction in reluctance motors, application of power electronics in AC drives and DC drives, power conversion systems and applications to industry, transportation and utilities and authored number of national and international journals. 